\title{
Phenylobacterium composti sp. nov., isolated from cotton waste compost in Korea
}

\author{
Hang-Yeon Weon, ${ }^{1}$ Byung-Yong Kim, ${ }^{2}$ Soon-Wo Kwon, ${ }^{2}$ Seung-Joo Go, ${ }^{2}$ \\ Bon-Sung $\mathrm{Koo}^{2}$ and Erko Stackebrandt ${ }^{3}$
}

Correspondence

Soon-Wo Kwon

swkwon@rda.go.kr

\author{
${ }^{1}$ Applied Microbiology Division, National Institute of Agricultural Science and Technology, Rural \\ Development Administration, Suwon 441-707, Republic of Korea \\ ${ }^{2}$ Korean Agricultural Culture Collection, Microbial Genetics Division, National Institute of \\ Agricultural Biotechnology, Rural Development Administration, Suwon 441-707, Republic of Korea \\ ${ }^{3} \mathrm{DSMZ}$ - Deutsche Sammlung von Mikroorganismen und Zellkulturen GmbH, Inhoffenstrasse 7b, \\ D-38124 Braunschweig, Germany
}

\begin{abstract}
A light-yellow-coloured bacterium, designated strain $4 \mathrm{~T}-6^{\top}$, was isolated from cotton waste compost in Korea. Cells of the strain were strictly aerobic, Gram-negative, motile (by means of single polar flagella) and rod-shaped. Optimal growth occurred at $30{ }^{\circ} \mathrm{C}$ and at $\mathrm{pH} 7.0-8.0$. The major fatty acids were 11-methyl $\mathrm{C}_{18: 1} \omega 7 c(23.8 \%), \mathrm{C}_{18: 1} \omega 7 c(23.2 \%), \mathrm{C}_{16: 0}(19.8 \%)$ and $\mathrm{C}_{17: 0}(14.8 \%)$. The DNA G $+\mathrm{C}$ content was $67.5 \mathrm{~mol} \%$. A phylogenetic analysis based on $16 \mathrm{~S}$ rRNA gene sequences revealed that strain $4 \mathrm{~T}-6^{\top}$ was a member of the genus Phenylobacterium, showing the highest sequence similarities with those of 'Phenylobacterium zucineum' HLK1 (98.8\%) and Phenylobacterium lituiforme DSM $14363^{\top}$ (98.4\%). However, the values for DNADNA relatedness between strain $4 \mathrm{~T}-6^{\top}$ and ' $P$. zucineum' HLK1 and $P$. lituiforme DSM $14363^{\top}$ were 45 and $43 \%$, respectively. Phylogenetic characteristics, physiological properties and DNADNA hybridization data indicate that strain $4 \mathrm{~T}-6^{\top}$ represents a novel species of the genus Phenylobacterium, for which the name Phenylobacterium composti sp. nov. is proposed. The type strain is $4 \mathrm{~T}-6^{\top}\left(=\right.$ KACC $12597^{\top}=$ DSM $\left.19425^{\top}\right)$.
\end{abstract}

The genus Phenylobacterium was first proposed by Lingens et al. (1985) for several soil isolates. At that time, the genus Phenylobacterium was described as consisting of aerobic, Gram-negative, non-motile, xenobiotic-compound-degrading bacteria having various cell shapes. Later, Kanso \& Patel (2004) emended the genus as comprising strict aerobes or facultative anaerobes and motile or non-motile bacteria. Phylogenetically, members of this genus formed a monophyletic group within the order Caulobacterales, class Alphaproteobacteria. At the time of writing, this genus comprises four recognized species: Phenylobacterium immobile (Lingens et al., 1985), Phenylobacterium lituiforme (Kanso \& Patel, 2004), Phenylobacterium falsum (Tiago et al., 2005) and Phenylobacterium koreense (Aslam et al., 2005); and 'Phenylobacterium zucineum' (Zhang et al., 2007).

During a study on the bacterial diversity of cotton waste composts used for the cultivation of the oyster mushroom (Pleurotus ostreatus), we isolated a strain designated $4 \mathrm{~T}-6^{\mathrm{T}}$. Strain $4 \mathrm{~T}-6^{\mathrm{T}}$ was isolated by means of the plating technique with trypticase soy agar (TSA; Difco) at $30{ }^{\circ} \mathrm{C}$.

The GenBank/EMBL/DDBJ accession number for the 16S rRNA gene sequence of strain $4 T-6^{\top}$ is EU022524.
The methods described by Smibert \& Krieg (1994) were used to test the following: Gram staining, catalase activity, oxidase activity and hydrolysis of casein, DNA, starch and Tween 80 . Hydrolysis of carboxymethylcellulose $(0.1 \%$, w/v), chitin $(1 \%, \mathrm{w} / \mathrm{v})$, hypoxanthine $(0.5 \%, \mathrm{w} / \mathrm{v})$, pectin $(0.5 \%, \mathrm{w} / \mathrm{v})$, tyrosine $(0.5 \%, \mathrm{w} / \mathrm{v})$ and xanthine $(0.5 \%, \mathrm{w} / \mathrm{v})$ was also tested. Bacterial cells were observed under phase-contrast microscopy (AXIO; Zeiss). Transmission electron microscopy (model 912AB; LEO) observation was performed with cells grown for 2 days at $30{ }^{\circ} \mathrm{C}$ on R2A (Difco). Anaerobic growth was assessed on R2A incubated in a GasPak anaerobic system (BBL). Growth tests with L-phenylalanine $\left(1.0 \mathrm{~g} \mathrm{l}^{-1}\right)$, chloridazon $\left(1.0 \mathrm{~g} \mathrm{l}^{-1}\right)$ and antipyrin $\left(1.0 \mathrm{~g} \mathrm{l}^{-1}\right)$ as sole carbon sources were determined in minimal medium $\mathrm{B}$ (Lingens et al., 1985) with vitamin $\mathrm{B}_{12}\left(0.03 \mathrm{mg} \mathrm{l}^{-1}\right)$ at $30{ }^{\circ} \mathrm{C}$. Other biochemical and physiological tests were performed using the commercial systems API 20NE, API ID 32GN and API ZYM according to the instructions of the manufacturer (bioMérieux). To determine the growth temperature, the strain was cultivated on R2A at 5, 10, 20, 30, 37, 40, 45 and $50{ }^{\circ} \mathrm{C}$. $\mathrm{NaCl}$ tolerance was studied using R2A broth supplemented with different concentrations of $\mathrm{NaCl}$. Growth at $\mathrm{pH} 4.0-10.0$ was evaluated in R2A broth. To test antimicrobial susceptibility, discs containing the following 
antibiotics were used: amikacin $(30 \mu \mathrm{g})$, ampicillin $(10 \mu \mathrm{g})$, cephalothin $(30 \mu \mathrm{g})$, cefotaxime $(30 \mu \mathrm{g})$, ciprofloxacin $(5 \mu \mathrm{g})$, chloramphenicol $(30 \mu \mathrm{g})$, erythromycin $(15 \mu \mathrm{g})$, fusidic acid $(10 \mu \mathrm{g})$, gentamicin $(10 \mu \mathrm{g})$, imipenem $(10 \mu \mathrm{g})$, kanamycin $(30 \mu \mathrm{g})$, lincomycin $(15 \mu \mathrm{g})$, meticillin $(5 \mu \mathrm{g})$, nalidixic acid $(30 \mu \mathrm{g})$, neomycin $(30 \mu \mathrm{g})$, netilmicin $(30 \mu \mathrm{g})$, penicillin $(10 \mathrm{U})$, polymyxin $\mathrm{B}(300 \mathrm{U})$, rifampicin $(5 \mu \mathrm{g})$, streptomycin $(10 \mu \mathrm{g})$, tetracycline $(30 \mu \mathrm{g})$ and vancomycin $(30 \mu \mathrm{g})$.

Strain $4 \mathrm{~T}-6^{\mathrm{T}}$ grew on R2A, TSA and nutrient agar (Difco). However, no growth was observed on MacConkey agar (Difco). The cells were aerobic, Gram-negative, motile (by means of single polar flagella) rods $0.5 \mu \mathrm{m}$ in width and $0.8-1.8 \mu \mathrm{m}$ in length. Colonies were light yellow in colour and irregular in shape on R2A. Phenotypically, strain $4 \mathrm{~T}-6^{\mathrm{T}}$ and P. lituiforme DSM $14363^{\mathrm{T}}$ were similar and could be differentiated from other members of the genus Phenylobacterium on the basis of the yellow colour of colonies, the presence of single polar flagella and the lack of oxidase activity and nitrate reduction. However, strain 4T$6^{\mathrm{T}}$ could be distinguished from P. lituiforme DSM $14363^{\mathrm{T}}$ in that the former was strictly aerobic, did not hydrolyse gelatin and utilized different substrates (including anti- pyrin and chloridazon). Strain $4 \mathrm{~T}-6^{\mathrm{T}}$ could be also differentiated from the close phylogenetic relative ' $P$. zucineum' HLK1 on the basis of the former's yellow pigmentation, absence of oxidase activity and nitrate reduction, hydrolysis of aesculin and gelatin and assimilation of sodium acetate, glycogen and lactic acid (Table 1).

The DNA G $+\mathrm{C}$ content of the isolate was determined with an HPLC method, as described by Mesbah et al. (1989), by using a reversed-phase column (Supelcosil LC-18 S; Supelco). The cellular fatty acid profile was determined by using the standard protocol of the Microbial Identification System (MIDI; Microbial ID) with cells that had been grown on R2A for 3 days at $30{ }^{\circ} \mathrm{C}$. The predominant fatty acids of strain $4 \mathrm{~T}-6^{\mathrm{T}}$ were 11 -methyl $\mathrm{C}_{18: 1} \omega 7 c(23.8 \%), \mathrm{C}_{18: 1} \omega 7 c$ (23. $2 \%), \mathrm{C}_{16: 0}(19.8 \%)$ and $\mathrm{C}_{17: 0}(14.8 \%)$ (Table 2). The fatty acid composition of strain $4 \mathrm{~T}-6^{\mathrm{T}}$ was unique in having such a large proportion (23.8\%) of 11-methyl $\mathrm{C}_{18: 1} \omega 7 c$. The DNA G +C content was $67.5 \mathrm{~mol} \%$.

The $16 \mathrm{~S}$ rRNA gene sequence of strain $4 \mathrm{~T}-6^{\mathrm{T}}$ was amplified by means of a PCR with conserved primers, as described by Kwon et al. (2003), and direct sequencing (Hiraishi, 1992). Multiple alignments performed with sequences of isolate $4 \mathrm{~T}-6^{\mathrm{T}}$ and those of members of the genera Phenylo-

Table 1. Differential phenotypic characteristics of strain $4 T-6^{\top}$ and recognized Phenylobacterium species

Strains: 1, 4T-6 ${ }^{\mathrm{T}}$ (P. composti sp. nov.); 2, P. falsum DSM $18556^{\mathrm{T}}$ (data from Tiago et al., 2005 and this study); 3, P. immobile DSM 1986 ${ }^{\mathrm{T}}$ (Lingens et al., 1985 and this study); 4, P. lituiforme DSM $14363^{\mathrm{T}}$ (Kanso \& Patel, 2004 and this study); 5, P. koreense KACC $11507^{\mathrm{T}}$ (Aslam et al., 2005 and this study); 6, 'P. zucineum' HLK1 (Zhang et al., 2007 and this study). For all strains, nitrate reduction, urease, hydrolysis of aesculin and gelatin and utilization tests (with the exception of antipyrin, chloridazon and L-phenylalanine) were conducted using API 20NE and API ID 32GN in this study. All strains are negative for indole production, glucose fermentation, arginine dihydrolase and urease. + , Positive; $(+)$, weakly positive; - , negative; ND, not determined.

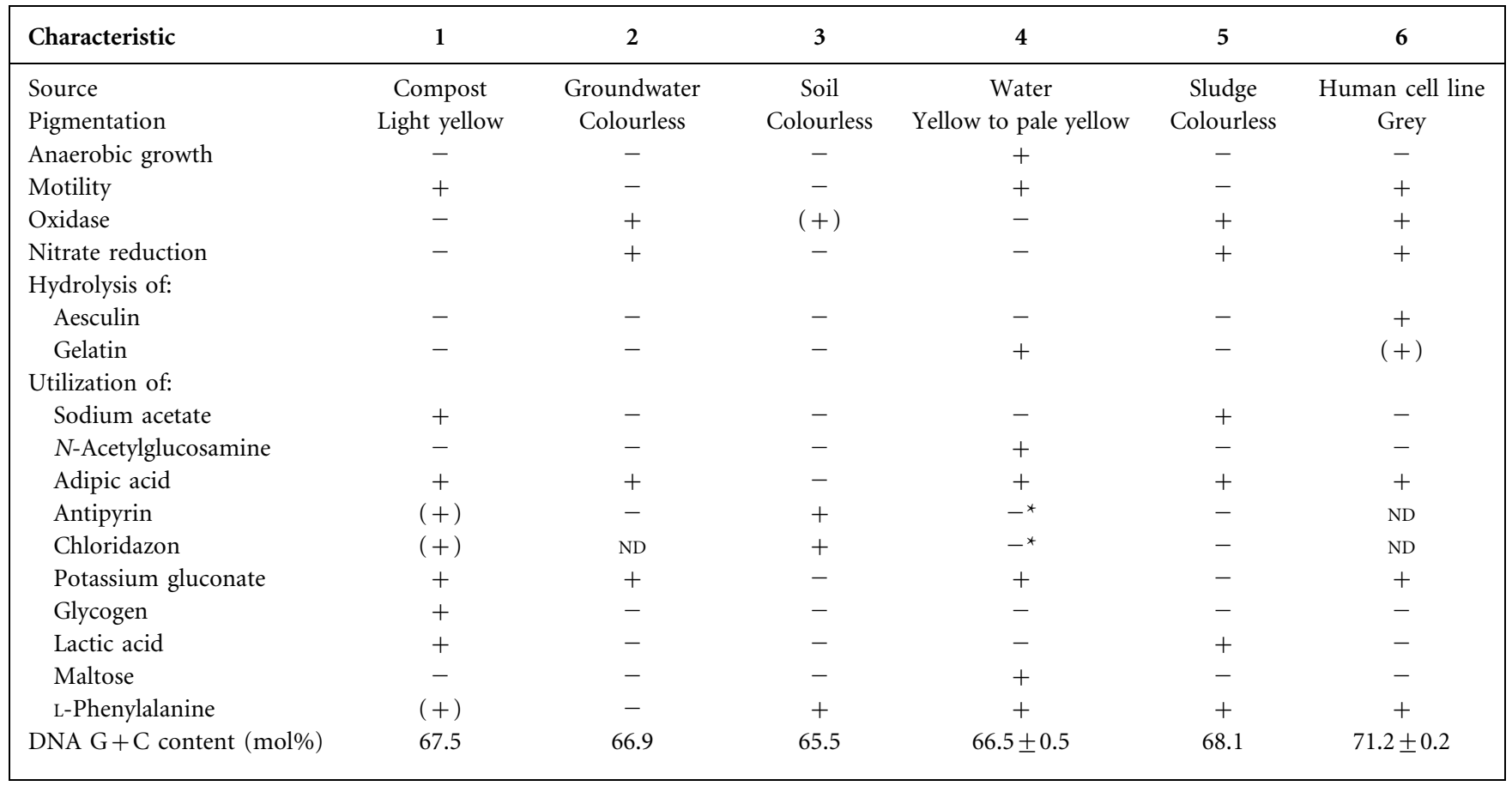

${ }^{\star}$ Data from Aslam et al. (2005). 
Table 2. Cellular fatty acid compositions (\%) of strain $4 T-6^{\top}$ and related strains

Strains: 1 , 4T-6 ${ }^{\mathrm{T}}$ (P. composti sp. nov.); 2, P. falsum DSM $18556^{\mathrm{T}} ; 3, P$. immobile DSM $1986^{\mathrm{T}} ; 4$, P. lituiforme DSM $14363^{\mathrm{T}} ; 5$, P. koreense KACC $11507^{\mathrm{T}}$; 6, 'P. zucineum' HLK1. Cells were harvested after growth on R2A for 3 days. -, Less than $1 \%$ or not detected.

\begin{tabular}{|lcccccc|}
\hline Fatty acid & $\mathbf{1}$ & $\mathbf{2}$ & $\mathbf{3}$ & $\mathbf{4}$ & $\mathbf{5}$ & $\mathbf{6}$ \\
\hline $\mathrm{C}_{12: 0}$ & 2.2 & 3.1 & 3.0 & 1.6 & 2.5 & 8.3 \\
$\mathrm{C}_{12: 0} 3-\mathrm{OH}$ & 1.8 & 1.1 & 1.0 & - & 1.0 & 6.1 \\
$\mathrm{C}_{12: 1} 3-\mathrm{OH}$ & - & 2.9 & 2.5 & 1.0 & 2.3 & 4.8 \\
$\mathrm{C}_{16: 0}$ & 19.8 & 8.6 & 16.5 & 13.4 & 18.3 & 9.9 \\
$\mathrm{C}_{16: 1} \omega 11 c$ & - & 2.7 & - & 1.6 & 1.9 & - \\
$\mathrm{C}_{17: 0}$ & 14.8 & 8.7 & 12.5 & 4.6 & 10.2 & 1.4 \\
$\mathrm{iso}_{\mathrm{C}} \mathrm{C}_{17: 0}$ & - & 2.8 & - & - & - & - \\
$\mathrm{C}_{17: 1} \omega 6 c$ & 3.0 & 5.4 & 3.7 & 2.1 & 3.7 & 1.6 \\
$\mathrm{C}_{17: 1} \omega 8 c$ & 2.1 & 3.9 & 2.9 & 1.4 & 2.3 & - \\
$\mathrm{C}_{18: 0}$ & 1.8 & - & 1.9 & 1.0 & - & - \\
$\mathrm{C}_{18: 1} 2-\mathrm{OH}$ & 2.5 & - & - & 5.4 & 3.2 & - \\
$\mathrm{C}_{18: 1} \omega 7 c$ & 23.2 & 55.7 & 43.6 & 58.3 & 30.3 & 59.6 \\
$11-\mathrm{Methyl} \mathrm{C}_{18: 1} \omega 7 c$ & 23.8 & 5.1 & 1.7 & 5.7 & 16.1 & - \\
$\mathrm{C}_{19: 0} \omega 8 c$ cyclo & 1.3 & - & 4.6 & - & - & 1.2 \\
$\mathrm{C}_{20: 0}$ & - & - & - & - & - & 5.2 \\
Summed feature $3^{*}$ & - & - & 1.7 & - & 4.2 & 2.1 \\
\hline
\end{tabular}

${ }^{\star}$ Summed feature 3 comprises $\mathrm{C}_{16: 1} \omega 7 c$ and/or iso- $\mathrm{C}_{15: 0} 2-\mathrm{OH}$.

bacterium, Caulobacter and other related species were carried out with the CLUSTAL W program (Thompson et al., 1994). The evolutionary tree for the datasets was inferred with the neighbour-joining and maximum-parsimony methods by using MEGA, version 3.1 (Kumar et al., 2004). The stability of relationships was assessed by performing bootstrap analyses based on 1000 resamplings. DNA-DNA hybridization was carried out using the filter hybridization method described by Seldin \& Dubnau (1985). Probe labelling was conducted using the non-radioactive DIGHigh Prime system (Roche) and hybridized DNA was visualized using the DIG luminescent detection kit (Roche). DNA-DNA relatedness was quantified by using a densitometer (Bio-Rad).
Strain $4 \mathrm{~T}-6^{\mathrm{T}}$ showed sequence similarities of $94.9-98.4 \%$ with respect to the type strains of the four recognized species of the genus Phenylobacterium, P. lituiforme DSM $14363^{\mathrm{T}}(98.4 \%), P$. koreense KACC $11507^{\mathrm{T}}(95.5 \%), P$. falsum DSM $18556^{\mathrm{T}}(95.3 \%)$ and P. immobile DSM $1986^{\mathrm{T}}$ ( $94.9 \%)$. The sequence similarity with ' $P$. zucineum' HLK1 was $98.8 \%$. Strain $4 \mathrm{~T}-6^{\mathrm{T}}$ showed less than $95 \% 16 \mathrm{~S}$ rRNA gene sequence similarity with respect to all of the other species of the genera included in this analysis. In the neighbour-joining phylogenetic tree (Fig. 1), strain $4 \mathrm{~T}-6^{\mathrm{T}}$ formed a robust cluster with the members of the genus Phenylobacterium, with $99 \%$ bootstrap support. The maximum-parsimony tree also supported the clear affiliation of strain $4 \mathrm{~T}-6^{\mathrm{T}}$ with the genus Phenylobacterium. The values for DNA-DNA relatedness between strain $4 \mathrm{~T}-6^{\mathrm{T}}$ and 'P. zucineum' HLK1 and P. lituiforme DSM $14363^{\mathrm{T}}$ were 45 and $43 \%$, respectively.

Therefore, the physiological, biochemical and phylogenetic properties of strain $4 \mathrm{~T}-6^{\mathrm{T}}$ support its description as representing a novel species within the genus Phenylobacterium, for which the name Phenylobacterium composti sp. nov. is proposed.

\section{Description of Phenylobacterium composti sp. nov.}

Phenylobacterium composti (com.pos'ti. N.L. gen. n. composti of compost).

Cells are motile (with single polar flagella), Gram-negative, rod-shaped bacteria $(0.5 \times 0.8-1.8 \mu \mathrm{m})$. Colonies on R2A are light yellow and irregular. Growth occurs at $15-45{ }^{\circ} \mathrm{C}$ (optimally at $30{ }^{\circ} \mathrm{C}$ ) and at $\mathrm{pH}$ 6.0-9.0 (optimally at $\mathrm{pH} 7.0-8.0)$. Optimum $\mathrm{NaCl}$ concentration is $0-1 \%(\mathrm{w} / \mathrm{v})$; no growth occurs at $\geqslant 3 \% \mathrm{NaCl}$. Catalase-positive and oxidase-negative. Nitrate is not reduced and glucose is not fermented. Hydrolyses Tween 80 and tyrosine, but not casein, chitin, carboxymethylcellulose, DNA, hypoxanthine, pectin, starch or xanthine. Negative for indole production, arginine dihydrolase, urease, aesculin hydrolysis, gelatin hydrolysis and $\beta$-galactosidase (API 20NE). Weakly utilizes antipyrin, chloridazon and L-phenylalanine. Utilizes potassium gluconate, adipic acid, suberic

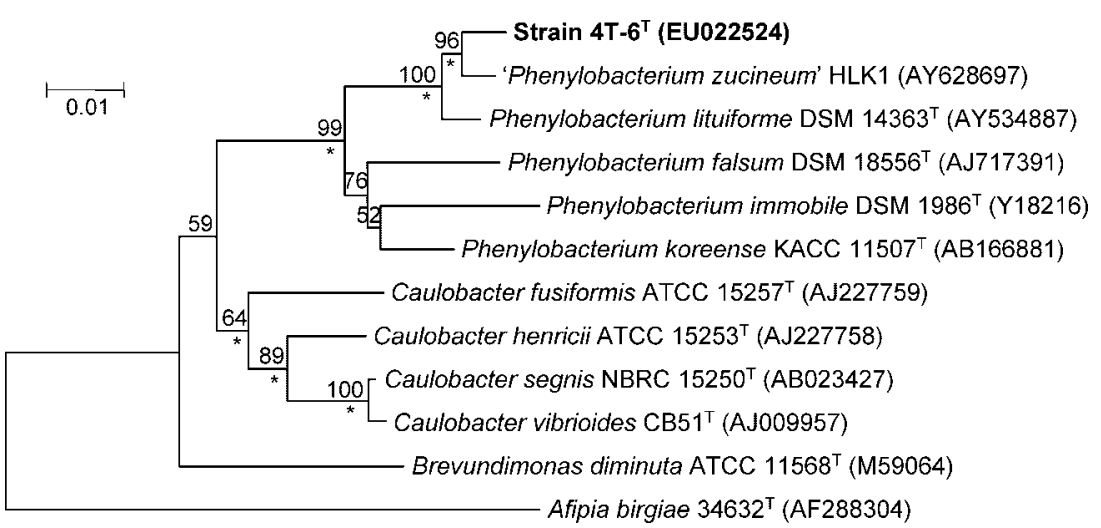

Fig. 1. Neighbour-joining phylogenetic tree, based on 16S rRNA gene sequences, showing the relationships between strain $4 \mathrm{~T}-6^{\top}$ and closely related species. Asterisks indicate that the corresponding branches were also recovered in the maximum-parsimony tree. Bootstrap values below $50 \%$ are not shown. Bar, 0.01 changes per nucleotide position. 
acid, sodium acetate, lactic acid, glycogen, valeric acid, 3hydroxybutyric acid and L-proline, but not D-glucose, Larabinose, D-mannose, D-mannitol, $\mathrm{N}$-acetylglucosamine, maltose, capric acid, malic acid, trisodium citrate, phenylacetic acid, L-rhamnose, D-ribose, inositol, sucrose, itaconic acid, sodium malonate, L-alanine, potassium 5-ketogluconate, 3-hydroxybenzoic acid, L-serine, salicin, melibiose, Lfucose, D-sorbitol, propionic acid, L-histidine, potassium 2ketogluconate or 4-hydroxybenzoic acid (API 20NE and API ID 32GN). Positive for alkaline phosphatase, esterase (C4), esterase lipase (C8), leucine arylamidase, valine arylamidase, cystine arylamidase, trypsin, acid phosphatase, naphtholAS-BI-phosphohydrolase and $\alpha$-glucosidase, but negative for lipase (C14), $\alpha$-chymotrypsin, $\alpha$-galactosidase, $\beta$-glucuronidase, $\beta$-glucosidase, $N$-acetyl- $\beta$-glucosaminidase, $\alpha$-mannosidase and $\alpha$-fucosidase (API ZYM). Resistant to fusidic acid, lincomycin, meticillin and nalidixic acid. Sensitive to amikacin, ampicillin, cephalothin, cefotaxime, ciprofloxacin, chloramphenicol, erythromycin, gentamicin, imipenem, kanamycin, neomycin, netilmicin, penicillin, polymyxin B, rifampicin, streptomycin, tetracycline and vancomycin. Major cellular fatty acids are 11-methyl $\mathrm{C}_{18: 1} \omega 7 \mathrm{c}$, $\mathrm{C}_{18: 1} \omega 7 c, \mathrm{C}_{16: 0}$ and $\mathrm{C}_{17: 0}$. The DNA G+C content of the type strain is $67.5 \mathrm{~mol} \%$ (HPLC).

The type strain, $4 \mathrm{~T}-6^{\mathrm{T}}\left(=\right.$ KACC $\left.12597^{\mathrm{T}}=\mathrm{DSM} 19425^{\mathrm{T}}\right)$, was isolated from cotton waste compost, in Korea.

\section{Acknowledgements}

This study was supported by the National Institute of Agricultural Biotechnology (grant no. 06-4-11-19-1), Rural Development Administration, Republic of Korea.

\section{References}

Aslam, Z., Im, W.-T., Ten, L. N. \& Lee, S.-T. (2005). Phenylobacterium koreense sp. nov., isolated from South Korea. Int J Syst Evol Microbiol 55, 2001-2005.
Hiraishi, A. (1992). Direct automated sequencing of $16 \mathrm{~S}$ rDNA amplified by polymerase chain reaction from bacterial cultures without DNA purification. Lett Appl Microbiol 15, 210-213.

Kanso, S. \& Patel, B. K. C. (2004). Phenylobacterium lituiforme sp. nov., a moderately thermophilic bacterium from a subsurface aquifer, and emended description of the genus Phenylobacterium. Int J Syst Evol Microbiol 54, 2141-2146.

Kumar, S., Tamura, K. \& Nei, M. (2004). MEGA3: Integrated software for Molecular Evolutionary Genetics Analysis and sequence alignment. Brief Bioinform 5, 150-163.

Kwon, S. W., Kim, J. S., Park, I. C., Yoon, S. H., Park, D. H., Lim, C. K. \& Go, S. J. (2003). Pseudomonas koreensis sp. nov., Pseudomonas umsongensis sp. nov. and Pseudomonas jinjuensis sp. nov., novel species from farm soils in Korea. Int J Syst Evol Microbiol 53, 21-27.

Lingens, F., Blecher, R., Blecher, H., Blobel, F., Eberspächer, J., Fröhner, C., Görisch, H., Görisch, H. \& Layh, G. (1985). Phenylobacterium immobile gen. nov., sp. nov., a Gram-negative bacterium that degrades the herbicide chloridazon. Int J Syst Bacteriol 35, 26-39.

Mesbah, M., Premachandran, U. \& Whitman, W. B. (1989). Precise measurement of the $\mathrm{G}+\mathrm{C}$ content of deoxyribonucleic acid by highperformance liquid chromatography. Int J Syst Bacteriol 39, 159-167.

Seldin, L. \& Dubnau, D. (1985). Deoxyribonucleic acid homology among Bacillus polymyxa, Bacillus macerans, Bacillus azotofixans, and other nitrogen-fixing Bacillus strains. Int J Syst Bacteriol 35, 151-154.

Smibert, R. M. \& Krieg, N. R. (1994). Phenotypic characterization. In Methods for General and Molecular Bacteriology, pp. 607-654. Edited by P. Gerhardt, R. G. E. Murray, W. A. Wood \& N. R. Krieg. Washington, DC: American Society for Microbiology.

Thompson, J. D., Higgins, D. G. \& Gibson, T. J. (1994). CLUSTAL W: improving the sensitivity of progressive multiple sequence alignment through sequence weighting, position-specific gap penalties and weight matrix choice. Nucleic Acids Res 22, 4673-4680.

Tiago, I., Mendes, V., Pires, C., Morais, P. V. \& Veríssimo, A. (2005). Phenylobacterium falsum sp. nov., an Alphaproteobacterium isolated from a nonsaline alkaline groundwater, and emended description of the genus Phenylobacterium. Syst Appl Microbiol 28, 295-302.

Zhang, K., Han, W., Zhang, R., Xu, X., Pan, Q. \& Hu, X. (2007). Phenylobacterium zucineum sp. nov., a facultative intracellular bacterium isolated from a human erythroleukemia cell line K562. Syst Appl Microbiol 30, 207-212. 